\title{
The Ethical Significance of Ziauddin Barni’s Fatwa-E Jahandari and its Contemporary Relevance
}

\author{
Dr. Sakina I. H. Khan
}

Head, Department of Persian

University of Mumbai

Mumbai, Maharashtra, India

dr.sakinakhan723@gmail.com

\begin{abstract}
Ziauddin Barni was the first Muslim to write the history of India. His close association with the ruling circles of Delhi enabled him to observe the administrative activities of the kings. Based on his experiences, he has documented the historical data in his works. His Fatwa-e Jahandari is a monumental work, which is a record of not only the historical facts but also a detailed account of the qualities of an ideal ruler. It enumerates and illustrates twenty four political ideals that should be part and parcel of a good ruler. This research paper focuses on ten values advocated by Barni, which could be viewed as an essential part of the ethical values. It showcases the significance of ethical leadership and offers an analysis of ten select values in the light of ethics. Subsequently, it depicts how the ethical values recommended by Barni are pertinent to the contemporary society.

Keywords: Ziauddin Barni; Fatwa-e Jahandari; qualities of an ideal ruler; political ideals; ethical values.

Introduction
\end{abstract}

Ziauddin Barni is said to be the greatest historian of early medieval India. He was born in 1286 at Baran in the reign of Sultan Balban. Bulandshahr is the present name of the 
place, Baran. Barni's father Muwayyid-ul-Mulk worked as a deputy (naib) in the court of Arkali Khan, the son of Jalaluddin Firuz Khalji. Barni occupied a high position under the Khaljis. He was a favourite companion of Muhammad bin Tughlaq for seventeen years. He was closely associated with the ruling circles of Delhi. Therefore, he had a wide knowledge of the period of the Delhi Sultanate. He was a distinguished scholar and had written several books. His two most notable works are Tarikh-e Firozshahi and Fatwa-e Jahandari. His fame as an historian mainly rests on his Tarikh-e Firozshahi, which covers the history of the Delhi Sultanate for a period of ninety-five years, from the accession of Balban to the sixth year of Firozshahi's reign. In his Fatwa-e Jahandari, Barni presents an analysis of various ethical qualities that a good monarch should possess. He offers in detail twenty four advices for a ruler to make his reign successful and morally good. This research paper seeks to explore ten of Ziauddin Barni's advices, which could be viewed in the light of ethics, and it elucidates how such values insisted and explicated by him are very much relevant to the contemporary society and the rulers of the present times.

\section{The Significance of the Ethical Leadership}

A nation or kingdom, in order to attain the noble characteristics of peace and harmony, should have good and selfless leaders or rulers, who are guided by the ethical values. The ethical commitment persuades the rulers as well as the subjects to strive towards honest, peaceful, tolerant and joyful society, wherein every individual is governed by the principles of love, equality and justice. It leads each one to become more and more human, empathetic, charitable, sincere, righteous and truthful. It ultimately paves the way for an egalitarian society. When a leader or ruler abides by moral values and renders ethically and lawfully good governance, the nation or the society, which is ruled by him or her, yields rich fruits of safety, goodness, justice and peace. Many scholars and writers, who had love for social welfare, had identified different qualities that are essential for good leadership. 
For instance, Chanakya, who is traditionally known as Kautilya or Vishnugupta, is renowned for his Arthashastra, in which he says, "An ideal king is one who has the highest qualities of leadership, intellect, energy and personal attributes" (Prasoon 97). According to him, the qualities of leadership are "birth in a noble family; good fortune, intellect and prowess; association with elders; being righteous, truthful, resolute, enthusiastic and disciplined; not breaking his promises; showing gratitude; having lofty aims; not being dilatory; being stronger than neighbouring kings; and having ministers of high quality" (Coxall 257). The quality of being righteous and truthful, which is one of the primary qualities of leadership highlighted by Chanakya, forms a part of ethical values that should be practised by rulers. It implies that ethical values are a prerequisite for being a righteous and effective leader. Stated differently, ethical leadership is an essential quality of an ethical leader. Ethical leaders are capable of making right decisions at right moment. Like Chanakya, Ziauddin Barni has also spoken of the essential ethical values required in a good leader.

\section{Analysis of the Ethical Values Underscored by Ziauddin Barni}

Ziauddin Barni asserts that a king or a ruler, in order to establish good governance in his kingdom, should possess various ethical values. In his work, Fatwa-e-Jahandari, he lays down twenty four advices as the basic principles of Government and as the good leadership qualities of kings. This paper makes a study of ten advices, which fall in the light of ethics and religious commandments. Barni's advices, which are rooted in the ethical ground, comprise the ensuing topics in his book:

- Advice II - On the Effects of the Good Faith of the King

- Advice III - On the Blessings of Consultation and Advice

○ Advice IV - On Correct Determination

- Advice V - On the King's Justice

- Advice VI - On the Grading of Officers and Notables 
○ Advice IX - On Price Control

- Advice $\mathrm{X}-$ On the King's Time

- Advice XI - On the Establishment of Truth at the Centre

- Advice XII - On the Administration of Justice

- Advice XIII - On the King's Mercy and Punishments

\subsection{Advice II: On the Effects of the Good Faith of the King}

The second advice put forth by Barni, in his Fatwa-e Jahandari, is on the 'effects of the good faith of the king,' and it has an ethical relevance. Barni affirms that a king should have strong faith in God: "If the king's faith in religion of the Prophet is firm and unshakable, then there is no harm..." (Begum 2) and the real test of his faith lies in "...how he keeps the inhabitants of his kingdom on the path of Religious law (Shari 'at)" (3). Barni adds that a faith-protecting king is the one, who is the cause of "good deeds, virtues and devotions" (3). It implies that when a king has a strong faith in God, he will follow the moral principles set forth by God, and will ensure righteous government for his people.

\subsection{Advice III: 'On the Blessings of Consultation and Advice': the Need for Humility}

The third instruction offered by Barni to the rulers calls for the humility of kings to seek the advice of the wise and experienced men, who are the well-wishers of the government and the chosen people of the kingdom. He considers the Prophets of God "the best and the greatest of all created beings" (8), and he declares that God Himself gave the following order: "And consult them in your affairs" (qtd. in Begum 8; The Quran, Sura III, verse 159). Experience, it is said, is "the mother of wisdom" (Manser 82). Therefore, the kings, in order to administer the affairs of the government, should consult the Prophets, the experienced officers and the well-wishers. Barni's advice indirectly designates the idea that the kings, however great and knowledgeable they are, should have the moral quality of humility to listen to the views of the good, wise and experienced persons and Prophets of his kingdom. 
According to ancient scholars, a king without a wise wazir is like a palace without foundation, and bread without salt. The wazirs of ancient days lay down the following tests for the good counsellor:

○ First, fear of God. If the counsellor has plenty of obstinacy and no fear of God, he will never be inspired with that correct judgment, which leads to good ultimate results.

- Second, knowledge of ancient kings. The counsellor should have knowledge of the circumstances of ancient kings and the policies through which they escaped calamities; if he does not possess this knowledge, his judgment will be defective.

- Third, practical knowledge of state affairs acquired as a confidential officer; such experience leads to maturity of judgment.

- Fourth, perfection of intelligence; a man of perfect intelligence discovers how to realize his aims with a little reflection.

- Fifth, perfect judgment in discerning character. If a person is not capable of correctly estimating the qualities of men, he will make blunders in the allotment of duties in government enterprises.

- Sixth, lack of greed. If the counsellor happens to be greedy and avaricious, his mind will not be inspired with correct judgment on account of his greed.

O Seventh, the counsellor ought to be stouthearted and firm of mind; correct judgment does not come to the hearts of the weak-willed and the lazy minded; nor does it inspire the faint-hearted.

- Eighth, the counsellor should have self-respect and the virtue of forgiveness; correct judgment cannot be expected from the hasty and the ferocious.

- Ninth, an inevitable condition for every counsellor is his sincere loyalty to the 
king, for this is the basis of all other virtues, especially in the hearts of the wise. (11)

Thus, it is obvious from the discussion above, that kings, according to Barni, should have the moral responsibility of consulting the wise and experienced people for discharging their duties in a right and effective way.

\subsection{Advice IV: On Correct Determination}

Correct determination, according to Barni, is another prerequisite of a good king. It is unquestionably a moral attribute because it signifies the ability to choose the right from the evil and the good policies, enterprises and the like. Barni regards correct determination as "the robe of kingship and the garb of royalty" (13). People will easily discern the political plans and schemes of a king, who has the quality of 'correct determination,' which will, consequently, lead to his immense reputation and the public confidence in him. A king's indulgence in defective and evil determinations is a mark of his tyranny and despotism. Correct determination, on the contrary, is a characteristic feature of a morally good king. In Barni's view, a king, before venturing into any enterprise or evolving and executing a policy among people, should first carefully examine the pros and cons of such enterprise or policy, reflect on all its aspects, and only then, make a determination so that it may generate a constructive and positive impact on the state, the religion and the people. In this regard, Barni says, "The kings of Islam in determining upon enterprises and managing their affairs should look to the 'determinations' and 'resolutions' of the Prophet and the Pious Caliphs" (14). Thus, it is quite essential for a king to acquire the quality of correct determination for making his regime highly successful and morally good, and for gaining the confidence and appreciation of his subjects.

2.4. Advice V: On the King's Justice 
Ziauddin Barni strongly believes that justice is the hallmark of a good society, characterized by good governance of a good ruler. Insisting on the fundamental need for justice in a kingdom or society, he claims that "...justice is the balance in which the actions of people, good or bad, are weighted. The distinction between righteous and wrongful claims is clarified by justice. Justice exposes cruelty, oppression, forceful misappropriation and plunder" (16). Barni, in his Fatwa-i Jahandari, considers justice an essential quality of an ideal ruler, and regards it as "a base of social organization and civil rights" (qtd. in "Judicial System"). In this regard, Parvin E'tesami's words, addressed to a king of Sasanian dynasty, in her poem, "Nama be Naushervaan" (Letter to Naushervaan)," are very much relevant: "If you step on a wrong path, then you will not find the right path ever,/ and if the people find you committing mistakes, they will do hundreds of sin" (233).

Parvin E'tesami's words showcase the prominence of the moral qualities of a king. That is, unless a king is morally righteous, he cannot ensure justice for his people. Observing that both ancient and modern intellectuals regarded 'religion' and 'justice' as twins, Barni says, "No religion, which is founded on Divine Commandments (ahkam), can do without justice" (Begum 16). He contends that the attribute of justice enables the king not only to protect the people from the evil forces of "tyranny and oppression" but also to safeguard "the money, property, women and children of the weak, the obedient, the helpless, the young, the submissive, and the friendless" (16). Therefore, Barni wants every ruler to possess the moral value of justice as his innate quality and to enforce this priceless quality among people.

2.5. Advice VI: 'On the Grading of Officers and Notables': the Need for Fairness and Honesty

In his sixth advice, Barni instructs the rulers to be fair in making the gradation of officers and notables in their kingdoms. He feels that it is the moral responsibility of the rulers to "confer rewards in recognition of every merit" (19). Good rulers, argues Barni, 
create general grades and ranks of merit based on "good birth, piety, nobility, wisdom, skill and morality" (20). It follows from Barni's views that rulers should be fair and honest in the creation of the grades and ranks, and in recognizing and rewarding the persons of merit. He is of the opinion that good kings, after creating general ranks and grades of the notables, share "a portion of that dignity and power, which God has bestowed upon [them], to every notable according to his birth and merits" (19), and they discharge "their obligations to every merit through the resources of their governments" (20). While discharging their obligations, the good kings always look at "everyone with the same eye" (20). It implies that the good kings are so morally righteous and just that they are impartial and unprejudiced, and treat their subjects and the notables in a fair way.

In this context, Barni cites the holy Prophet, who says: 'Give to every true claimant his due.' A king of wisdom, after putting his subjects into defined ranks and grades, deals with both the common people and the notables in a correct and appropriate way. The rightful claimants are always duly rewarded by him. To substantiate his argument, Barni quotes the words of Ardshir Babakan, who says, "He alone can be considered a righteous king who in his dealings with the people has regard for their ranks and grades, so that all his subjects become his loyal well-wishers" (19). In this sense, recognizing and rewarding the right persons for their rights acts at the right time could be viewed as a moral value that is required in a good ruler because it enables the ruler to be honest in his actions.

\subsection{Advice IX: On Price Control}

Barni's advice on 'price control' implicitly exhibits the values of integrity and generous and prudent attitude required in the kings. Barni affirms that prices of things should be determined based on the production-cost, and it is always a fundamental duty of the kings to keep the prices of the requisites of the army and the common people under control. In this context, he recommends the "[i]ntelligence officers and honest and harsh-tempered judges" to 
"control the transactions of buying and selling" and to "make excessive enquiries and investigation about them" (35). A proper organization of the army necessitates low price of commodities. Likewise, the valuable attributes of prosperity, splendour and stability among people in a kingdom demand from the king the cheap price of the means of people's livelihood. Therefore, the cheap price of the means of people's livelihood, according to Barni, is the basis of the kings' "good management of the country and of their administration of justice" (35).

The people will have tremendous affection for the king, who endorses lower price of the requirements of the people's livelihood. The low-priced requisites of the army and the necessities of the people's livelihood give birth to several religious and worldly benefits, which will, ultimately, contribute to the welfare of both the kings and their subjects (36). Barni is confident of the fact that only the king, who never permits the "mishandling of the helpless, the poor, the infirm, the distressed, the young and the ignorant by knaves, rogues, shop-keepers and shameless and God-less people," can be called "the shadow of God or a legitimate ruler" (36). It unveils the idea that it is the moral responsibility of the king not only to safeguard the common people particularly the poor and the needy from the evils of exploitation, abuse, deceit, violence and maltreatment, but also to make it feasible for the common people to get their required things at lower price.

\subsection{Advice X: On the King's Time}

Time is a precious dimension of each one's life. Sunday Adelaja says, "Understanding the value of time is understanding the true essence of life" ("Value of Time"). This concept of time unveils the real worth of time. Barni's tenth advice, in his Fatwa-i Jahandari, lays emphasis on the significance of king's time, which could be looked at from an ethical perspective. Barni affirms that every king should realize that time is a great blessing of God, 
and he should, therefore, recognize its value. He should, first, devote some time to God by performing religious duties to Him, and then make use of the time in a judicious and upright way to administer the affairs of the government. This will bring him closer to God. The king should never waste his precious time in pursuit of worldly pleasures. He should, instead, allocate adequate time to attend to every work carried out by him, particularly the government affair to complete it successfully (41). This idea of Barni designates the fact that utilizing the time for discharging the duties in a right way and for doing good works paves the way for moving towards God. In this sense, it is a moral path to reach God.

\subsection{Advice XI: On the Establishment of Truth at the Centre}

In order to administer the affairs of the government in a right way, and in order to attain spiritual progress and salvation, a king, asserts Barni, should strive to establish truth at the centre. In this context, Barni is reminded of the Sultan Mahmud's observation that the establishment of truth at the centre does not imply the sole presence of truth and the complete absence of falsehood. He also remembers the words of the Almighty God, who says: "Of everything We have created pairs" (qtd. in Begum 43; The Quran, Sura 51, verse 49). Barni, thus, admits the reality of the presence of the opposing elements in the world such as truth and falsehood, peace and disorder, the good and the evil, devotion to God (i.e., goodness) and sinfulness, obedience and disobedience, day and night, and so forth. He is also well aware of the fact that it is impossible to completely uproot from the world the following negative forces:

infidelity, polytheism, wickedness, mischief, falsehood depravity, lying, uttering of false coins, drunkenness, adultery, sodomy, anger, victimization of innocent persons, injustice, cruelty, lawless overpowering of others, misappropriation, rebellion, disorder, trespassing the limits of justice, enmity, revolt, disobedience, dishonesty, cheating, fraud, misrepresentation, violation of the rights of parents, disloyalty, false 
accusations, framing of false charges, evil-speaking, slander, calumny, impiety, jealousy, ill-will, lack of self-respect, shamelessness, treachery, theft, sedition, highway robbery, usury, regretting, ingratitude, non-recognition of rights, adulteration of commodities, and commission of unlawful and disapproved acts. (Begum 44)

For, if it were possible to eliminate these evil forces completely from the world, all kingdoms would have been "united into one state and all false creeds overthrown" (44). But it is not practically possible. Therefore, Barni accepts the limitation of the impossibility of complete overthrow of evils. However, he strongly believes that "...the real meaning of 'truth being established at the centre' is that truth shall overpower falsehood and falsehood shall not overpower truth, so that the honour of truth and the greatness of Islam may be vindicated through the humiliation and disgrace of polytheism and infidelity" (44; italics in the original). Therefore, he insists the kings to take efforts to establish truth in his kingdom so that it could overpower falsehood and promote righteousness. Thus, it is apparent in the advice of Barni that the establishment of truth at the centre is a significant attribute of ethics because it plays a vital role in creating the ground for the progress of good values and in overpowering falsehood. Thus, it assists the kings as well as the subjects to do good and avoid evil.

2.9. Advice XII: On the Administration of Justice

Barni's twelfth advice, which is on 'the administration of justice,' is a supplement to his fifth advice wherein he elaborates on the need for king's justice. Administering justice is a distinct mark of a great and righteous ruler.

2.9.1. Ruler's Innate Sense of Justice: the Twenty Qualities of a Distinct Ruler

Concerning the administration of justice, Barni feels that a good ruler should possess an innate sense of justice. In this context, he is sturdily in agreement with the view of the 
wise men (hakims), who proclaim that the following twenty qualities distinguish a ruler, who is gifted with an inherent sense of justice:

(1) Kinship with the oppressed, desire to protect the weak, hatred of the unjust and enmity of the oppressors is written in his heart.

(2) He has no feeling of retaliation or revenge, even when he is giving judgment against his own enemies.

(3) $\mathrm{He}$ is incapable of making compromises or tolerating wrongs or exceeding proper limits where justice is concerned.

(4) His heart trembles lest the innocent be punished.

(5) No one can influence him where the administration of justice is concerned.

(6) He cares neither for the criticism nor the approval of men when he is passing judicial judgments.

(7) No consideration of any harm to himself or to his government can prevent him from enforcing justice.

(8) He is incapable of self-deception and does not make his principles flexible.

(9) Though stern in enforcing the just claims of others, yet he prefers to be forgiving where he is personally concerned.

(10) He finds no peace in his heart till he has exacted the claims of the weak from the strong.

(11) He avoids putting himself under the obligations of others from fear that these obligations may influence his mind (as a judge).

(12) Though he seeks justice, yet his heart is kind and affectionate.

(13) His just anger is for the sake of God only and no animal passions of hostility are excited in him.

(14) In his heart he hates his power as the supreme commander because it entails 
the obligation of passing orders against the honour and the blood of Musalmans.

(15) His mind instinctively rejects deceptions, lies, false excuses and trickeries, for the touch-stone of intelligence for distinguishing the false from the true is present in his breast.

(16) He desires that all cases appertaining to his subjects should be decided by him personally.

(17) Love for such a ruler is inscribed in the hearts of his subjects, and even if the injuries are caused by his orders, his subjects do not hate him on that account.

(18) His heart beats restlessly if he hears of any case of injustice or wrong in east or west.

(19) His mind is always absorbed in thoughts of overthrowing the unjust and enforcing justice.

(20) When dealing with peaceful men, he is guided by the precept that 'punishment should be based on evidence', but when dealing with oppressors, sinners and criminals, who are by their nature inclined to wrong-doing, he does not allow doubts (about their guilt) to sway his mind. (52-53)

\subsubsection{The Need for Special and Universal Equality}

Barni contends that a ruler, in addition to possession of the above-mentioned qualities, which mark his innate sense of justice, should also have the ability to enforce special and universal equality. Frances Wright writes, "Equality is the soul of liberty; there is, in fact, no liberty without it" (Sanders 52). In this sense, there cannot be justice without equality. According to Barni, justice, for early and later kings, meant "putting all litigants on a par and enforcing equality between them" (Begum 53). But early religious scholars of the correct Faith categorized justice into two types namely 'special equality' (masawat-i khas) and 'universal equality' (masawat-i 'am). Accordingly, special equality implies "the equality of 
litigants before the ruler, because justice is no respector of persons," whereas universal equality designates "the equality of the ruler and the ruled" or "the equality of the ruler (with his subjects)" (53).

Barni identifies a significant distinction between 'special equality' and 'universal equality.' According to him, 'special equality' is "confined to the equality of the litigants only," and is associated with the situation wherein the caliph or king or anyone who is assigned with the power of making decision "enforces equality between the accuser and the accused," and "treats them equally during the trial with reference to their speeches and actions, and (the privilege of) sitting and standing before him, and does not give preference to either party for any cause." Furthermore, in his task of administration of justice, the ruler always "looks with same eye at relations and strangers, the distinguished and the ignoble, the employed and the unemployed, officers and citizens, rich and poor, nobles and commons, supporters and opponents, friends and foes," and he never receives any "gifts, bribes, presents or souvenirs, valuable or cheap, from either party" (53).

'Universal equality,' in Barni's view, is “a consequence of the perfection of piety and an exclusive feature of the four Pious Caliphs of the Prophet's Faith" and it "has ended with Abu Bakr, 'Umar-i Khattab, 'Usman and 'Ali Murtaza” (53). However, Barni recognizes that "the radiance of 'universal equality' has also shone on the reign of 'Umar bin Abdul Aziz" (54). Admiring the greatness and the noble qualities of the Caliph, he writes:

The Caliph, who wields the powers of a Jamshed or a Khusrau over realms subordinate to his orders, not only discharges the obligations of 'special equality' between litigants but lives in the same way as the faqirs and the poor people of the community. In spite of his great authority and status he prefers a life of poverty. He passes his days in indebtedness, in distress and in lack of material means; his food and dress is the same as of the poorest people. He does not take from the Public Treasury 
more than he requires for the minimum needs of his life and he eats and dresses in the same way as his slaves. And this achievement, which appears to be the harmonisation of two opposites-kingship and poverty-has been considered a miracle of the Prophet and a wonderful achievement of the Pious Caliphs. (54)

Barni is cognizant of the fact that 'universal equality' is "beyond the attainment of Muslim kings." However, he insists those kings to "strive for "special equality" and he instructs them in particular to "be personally accessible to the victims of oppression." Thus, Barni wants the rulers to realize the fact that "God maintains the earth and the heavens (samawat) through justice" (54). Justice is an important component of ethical values, and it should be practised not only by the rulers but also by every human person.

\subsection{Advice XIII: On the King's Mercy and Punishments}

Forgiveness is a difficult and noble quality, which finds a remarkable place in the realm of ethics. It is to be remembered that "justice without mercy is tyranny" (qtd. in Cohen 193). Barni looks at the ethical values of forgiveness and mercy in the light of Quranic commandments. That is why, in his advice on 'king's mercy and punishment,' he convincingly reveals that since "God is the forgiver of sins, the acceptor of repentance and strict in His punishments" (The Quran, Sura XL, verse 3), the king must behave in accordance with this Quranic verse, and must be merciful and have the forgiving heart so that he might have happiness during his life-time, and his reputation might remain alive even after his death. He adds that God-fearing kings have strongly believed that "Kingship cannot be properly established without forgiveness and punishments," and therefore, a far-sighted king always "knows well the correct occasions for forgiveness and punishment" (56). He fittingly recalls to his mind the instruction of Sultan Mahmud that a king should be well aware of the fact that "the forgiving, overlooking, disregarding and veiling of faults is one of the duties and obligations of kingship" (55), which will pave the way for a peaceful life and happiness. 
It is the ethical or moral duty of a king to establish peace and happiness of his subjects in his country. He should make sure that none of his subjects remains in bondage. A great and good king aims at keeping his people happier, safer and more peaceful in all possible ways.

\section{The Ethical Relevance of Ziauddin Barni' Fatwa-e Jahandari to Contemporary Society}

The select values that have been analysed so far are a significant part of ethics. The ethical values recommended by Barni in his Fatwa-e Jahandari are undeniably relevant to the contemporary society. Today, the rulers, who lack moral values, strive to exploit, deceive and plunder the common people and the public money for gratifying their selfish motives. Many of the powerful and developed nations employ the tools of power, weapons and violence to loot the poor nations and their natural resources. Aristotle and many great thinkers claim that "political thinking is grounded in ethical thinking" (Guha). If politics lacks ethical values, the well-being of the nation and the people will be ruined. But most unfortunately, today's politics is devoid of ethical values. The politicians, who deviate from the ethical values, are corrupt, selfish, rude and unjust, and they misuse the power and money for their selfish and personal gains. They attempt to generate rift, disharmony and violence in the society on the basis of religion, caste, language and other barriers.

The sole aim of most of the politicians who are in power today is to loot the public money, exploit the people, divide the people and fulfill their selfish motives. They often would like to satisfy the wishes of the rich and the corporate sectors, who offer crores and crores of money as bribe to them, and who seek to exploit and destroy the poor and the natural environment. The welfare and happiness of the common people have vanished from mind of the persons in power. Most of the policies made by them make the rich richer and the poor poorer. They also devastate the well-being of the natural environment. Bribe and corruption have become part and parcel of the government affairs. People, in order to get their works done in public or government offices, are compelled to pay bribes to the officials 
and politicians. Even in government appointments, bribe plays a vital role, and therefore, many candidates, who have real merit, are unable to get appointments because of their inability to pay the bribe demanded by the people in power. In several contexts, the persons' real merit has no significance in today's world. Many persons, who are involved in several crimes, are able to succeed to come to power. The common people are often bought with money to cast their votes for the immoral candidates. The absence of ethical values in the political and government administration in the contemporary world has contributed immensely to the progress of poverty, chaos, disharmony, exploitation, murder, violence and other sins.

Hence, it is the need of the hour to pay attention to the practice of ethical values particularly in political and government administration. It is in this context that Barni's Fatwa-e Jahandari is highly relevant to today's world because it beautifully and clearly teaches and illustrates the important ethical values that should be practised by the rulers and the people in power. It is true Barni enumerated and explained the ethical values for the kings. However, the values illustrated by him are relevant to the rulers of all nations and all ages. Accordingly, the ethical values analysed in this paper are pertinent to the rulers of the present times as well. As suggested by Barni, the rulers should posses the ethical values to generate good governance and other features such as harmony, peace, equality and happiness of people. Therefore, only those people, who posses moral values and who advocate secularism and religious harmony, should be elected to come to power.

\section{Conclusion}

Barni wrote his book, Fatwa-e Jahandari, with the key intention of teaching the rulers particularly the Muslim kings the principles of kingship and kingdom from ethical, political, economic and administrative viewpoints. To accomplish his aim, he had employed ancient anecdotes historical events, Quranic verses and the commandments of Almighty God in order 
to enrich the ethical values in a kingdom or society. Ethics has no religion, because every religion and every religious book teaches ethical values. Even though Barni's Fatwa-e Jahandari was written in the $14^{\text {th }}$ century A.D. specifically for Muslim kings, it crosses the barriers of ages, languages, nations, religions and other such differences, and has immense relevance to contemporary society. It is a wonderful archive of the essential morals that are required in every ruler, and therefore, it is reliable and more relevant to the rulers and the people of the present times.

Here, in order to present the gist of Barni's ethical advices given in Fatwa-eJahandari, it is quite fitting to cite two verses of the $20^{\text {th }}$ century renowned poetess, Parvin E’tesami, from her poem, "Nama be Naushervaan" (Letter to Naushervan), wherein she narrates dialogue between King Naushervan and his minister Bozorgmehr: "Bozorgmehr wrote to Naushirvan that the people demand their safety and welfare from a king./ If the king tries for instauration of his country, there will be no need for the establishment of any formal court" (233). It is quite evident from the analysis of the ethical values posited by Barni in Fatwa-e Jahandari that when a ruler parctises the ethical values in his or her life, his or her country will be filled with the blessings of security, peace, prosperity and the welfare and happiness of people. 


\section{References}

Begum, Afsar, translator. "Fatwa-e Jahandari" by Ziauddin Barni. Political Theory of the Delhi Sultanate by Mohammad Habib and Afsar Umar Salim Khan, Allahabad, Kitab Mahal, ia601603.us.archive.org/7/items/in.ernet.dli.2015.120819/2015.120819.ThePolitical-Theory-Of-The-Delhi-Sultanate.pdf.

Cohen, Richard A. Elevations: the Height of the Good in Rosenzweig and Levinas. Chicago, U of Chicago P, 1994.

Coxall, Eric. The Cosmic Symphony, vol. 1. Scarborough, UK, Farthings Publishing, 2016.

E’tesami, Parvin. "Nama be Naushervaan" (Letter to Naushervan). The Divan-e Parvin E'tesami, edited by Farideh Danayi, ${ }^{\text {nd }}$ ed., Tehran, 1373AH, p. 233.

Guha, Keshava. "Politics without Ethics." Pragati, 2 May 2017, https://www.thinkpragati.com/opinion/1334/politics-without-ethics/.

"Judicial System in Pre-Mughal Period," shodhganga.inflibnet.ac.in/bitstream/10603/16633/8/08_chapter\%203.pdf.

Manser, Martin H. Facts on the File Dictionary of Proverbs, $2^{\text {nd }}$ ed. New York, Facts on File, 2007.

Prasoon, Shrikant. Chanakya: Rules of Governance by the Gurus of Governance. New Delhi, V\&S Publishers, 2013.

Sanders, Mike. Women and Radicalism in the Nineteenth Century: Frances Wright, vol. 2. London, Routledge, 2001.

"Value of Time Quotes." Goodreads, www.goodreads.com/quotes/tag/value-of-time. 